\title{
Visualization Analysis of Curriculum Ideological and Political Research in China from the Perspective of Bibliometrics
}

\author{
Zhangsheng Liu*, Shuiwu Zhu, Guihai Liu \\ College of City Construction, Jiangxi Normal University, Nanchang, China \\ Email: *liuzs8033@hust.edu.cn
}

How to cite this paper: Liu, Z. S., Zhu, S. W., \& Liu, G. H. (2019). Visualization Analysis of Curriculum Ideological and Political Research in China from the Perspective of Bibliometrics. Creative Education, 10, 2201-2218.

https://doi.org/10.4236/ce.2019.1010159

Received: September 19, 2019

Accepted: October 20, 2019

Published: October 23, 2019

Copyright (c) 2019 by author(s) and Scientific Research Publishing Inc. This work is licensed under the Creative Commons Attribution International License (CC BY 4.0).

http://creativecommons.org/licenses/by/4.0/

\begin{abstract}
Using the software CiteSpace, this research sorts out the literature of curriculum ideological and political research in SCI source journals, EI source journals, core journals, CSSCI and CSCD journals in the CNKI database, in order to provide more objective and scientific reference in this field. The research shows that domestic scholars mostly enhance their understanding of the ideological and political concepts in curriculum from the perspective of the distinction between basic connotations and related concepts; discuss the theoretical basis and value implication of curriculum ideological and political education from multiple dimensions; research generating path of curricular ideological and political education from the "three elements" path and the "four elements" path; explore the teaching reform from five aspects: curriculum system setting, teaching methods, construction of teaching staff, implementation of subjective responsibility and building of institutional mechanism. With the continuous development of practice, relevant research is shifting from the stage of "Ideological and Political Courses" to the stage of "Ideology and Politics Teaching in All Course", and the development trend from the "two skins" stage to the "melting furnace" stage. Under the new situation, experts and scholars should strengthen the study of the practical path of integrating ideological and political education into course teaching to provide an operational and reproducible implementation paradigm for relevant practices.
\end{abstract}

\section{Keywords}

Curriculum Ideological and Political Education, Bibliometrics, Knowledge Map, Visualization

\section{Introduction}

In recent years, with the continuous deepening of the reform and opening up 
process, the diversified social ideology and culture have been intertwined and mutually excited, which has caused problems to college students' thinking to a certain extent. To this end, General Secretary Xi Jinping stressed at the National Conference on Ideological and Political Work in Colleges and Universities: "To make good use of the main channel of classroom teaching, the ideological and political theory course should be strengthened through improvement, so as to enhance the affinity and pertinence of ideological and political education and meet the needs and expectations of students' growth and development. All other courses should cultivate a good field of responsibility so that all kinds of courses and ideological and political theory courses can go in the same direction and form a synergistic effect". This pointed out the advancement aspect for further strengthening the ideological and political education work in colleges and universities, and triggered a high-degree of attention and in-depth discussion on the "curriculum ideological and political education" research in the academic circle.

At present, the domestic curriculum-based ideological and political research has become a major topic and research hotspot in the academic world. Therefore, combing and summarizing the existing research results is of great significance to promoting ideological and political education in colleges and universities. However, only a very small number of scholars have reviewed the study of "curriculum ideological and political" from a qualitative perspective. No scholars have visually analyzed the curriculum ideological and political research from the perspective of bibliometrics. In view of this, from the bibliometric perspective, on the basis of combing the relevant literature of curriculum ideological and political research in China, this paper uses CiteSpace, a visual analysis software, to analyze the research status, research hotspots and evolution trend of curriculum ideological and political research, in order to provide scientific reference for strengthening the research of curriculum ideological and political in Chinese universities.

\section{Data Sources and Research Methods}

\subsection{Data Source}

To ensure the objectivity and representativeness of the research data, this paper uses the China National Knowledge Infrastructure (CNKI) as the data source, and uses the advanced search function of the database to define the scope of the search as SCI source journals, EI source journals, core journals, CSSCI journals, and CSCD journals, the search time is set to June 30, 2019, and the search method is set to "accurate". As a result, a total of 220 journal articles were searched, and 175 articles of effective research were finally obtained by further excluding and screening documents that did not meet the research requirements, such as documentary, book review, and news reports.

\subsection{Research Methods}

This paper combined bibliometric theory with visual analysis method. Firstly, 
the effective samples of selected domestic curriculum ideological and political research are exported in Refworks literature format; Secondly, the exported data is transformed into format by using visual analysis software CiteSpace, and the data files recognized by the software are further output; Thirdly, using CiteSpace to perform co-occurrence analysis of the author, organization and keywords on the identifiable file data, on the basis of which the scientific knowledge map with spatio-temporal features is drawn; Then, the characteristics analysis and in-depth exploration of scientific knowledge maps are respectively carried out; Finally, this research summarizes the relevant conclusions of ideological and political research in domestic curriculum, and explore the development trend of future curriculum ideological and political research.

\section{The Analysis of the Current Situation of Curriculum Ideological and Political Research}

\subsection{Annual Distribution of Journal Articles}

This paper takes the annual number of papers published in the journal paper as the index, and draws the annual distribution map of the ideological and political journal articles of the domestic curriculum from 2007 to 2019 (Figure 1). Based on this, we can understand the macroscopic representation and research heat of the curriculum policy in China. As shown in Figure 1, from the perspective of time, the study of domestic curriculum ideological and political development presents three stages of development characteristics. 1) Budding stage (2007-2010): In 2007, for the first time in China, articles related to curriculum ideological and political issues appeared. However, due to the objective needs of developing the economy at that time, domestic scholars ignored the research in this field to some extent. The neglect of the research has caused its research to appear sporadically in the following years, and there is a phenomenon of "vacancy" in a

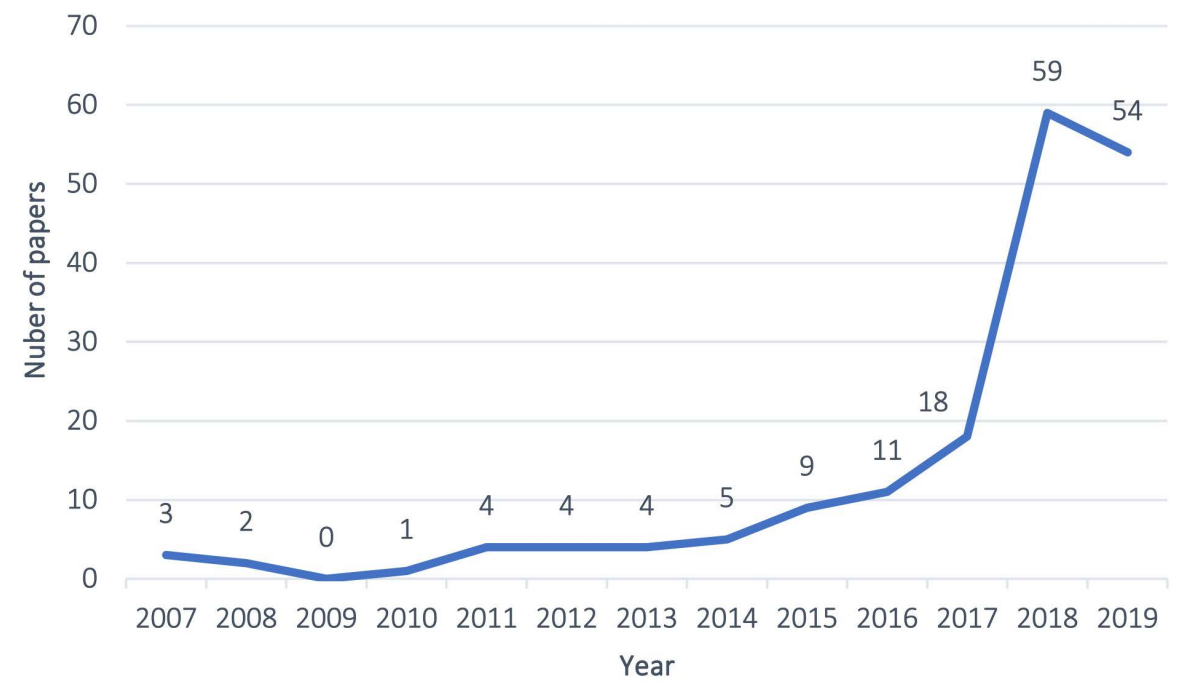

Figure 1. Annual distribution of curriculum ideological and political articles from 2007 to 2019 . 
specific year; 2) A stage of steady development (2011-2016): With the deepening of the reform and opening-up process and the increasing demand for ideological level, experts and scholars have paid more and more attention to the study of curriculum ideological and political education, which has laid a solid foundation for the formal presentation of the concept of "curriculum ideological and political education", and its external characteristics is steady growth of the number of the documents during this stage; 3) Rapid developing stage (2017-2019): Under the background of the new era, the ideological and political work has aroused the attention of the Party Central Committee, which has heated up the research in this field and greatly promoted the study of China's curriculum ideological and political studies into the fast lane. It is reflected in the rapid increase in the number of related documents. Based on the law of the change in the number of documents and the objective reality of the construction of socialist ideology in China, it can be predicted that future research on ideological and political studies will continue to surge.

\subsection{Author Cooperation}

This article uses CiteSpace to conduct statistics on the authors of the curriculum ideological and political research in CNKI from 2007 to 2019, and draws the author's cooperative network map (Figure 2). It can be seen from Figure 2 that among the authors who have cooperative relations in China, there is a seven-person cooperative team represented by Chen Xiaoyong, a five-person cooperative team represented by $\mathrm{Xu}$ Jialiang, three four-person cooperative teams represented by Miao Yuehong, Pan Rongjun and Liu Shuming, and several "two-person or three-person" small teams. It is worth noting that a considerable number of authors are usually issued independently and rarely form partnerships with others.

In summary, we can see that there are only 5 teams (Number of authors is greater than 3) with close cooperation in the field of domestic curriculum ideological and political education, and few research teams have "star" and "network" cooperation relations, which indicates that there is still much room for the development of cooperation among the authors of curriculum ideological and political research, and the degree of cooperation and cooperation links need to be further strengthened.

\subsection{Institutional Cooperation}

This paper uses CiteSpace software to visually analyze the research institutions of the curriculum and the ideological and political education in CNKI from 2007 to 2019, and generate an organization cooperation network map (Figure 3) to understand the cooperation of research institutions. It can be seen from the figure that most of the cooperation between research institutions is "single strip" and "triangular". There is only one "square-like" cooperative network consisting of the Student Work Research Branch of the Chinese Association of Higher 


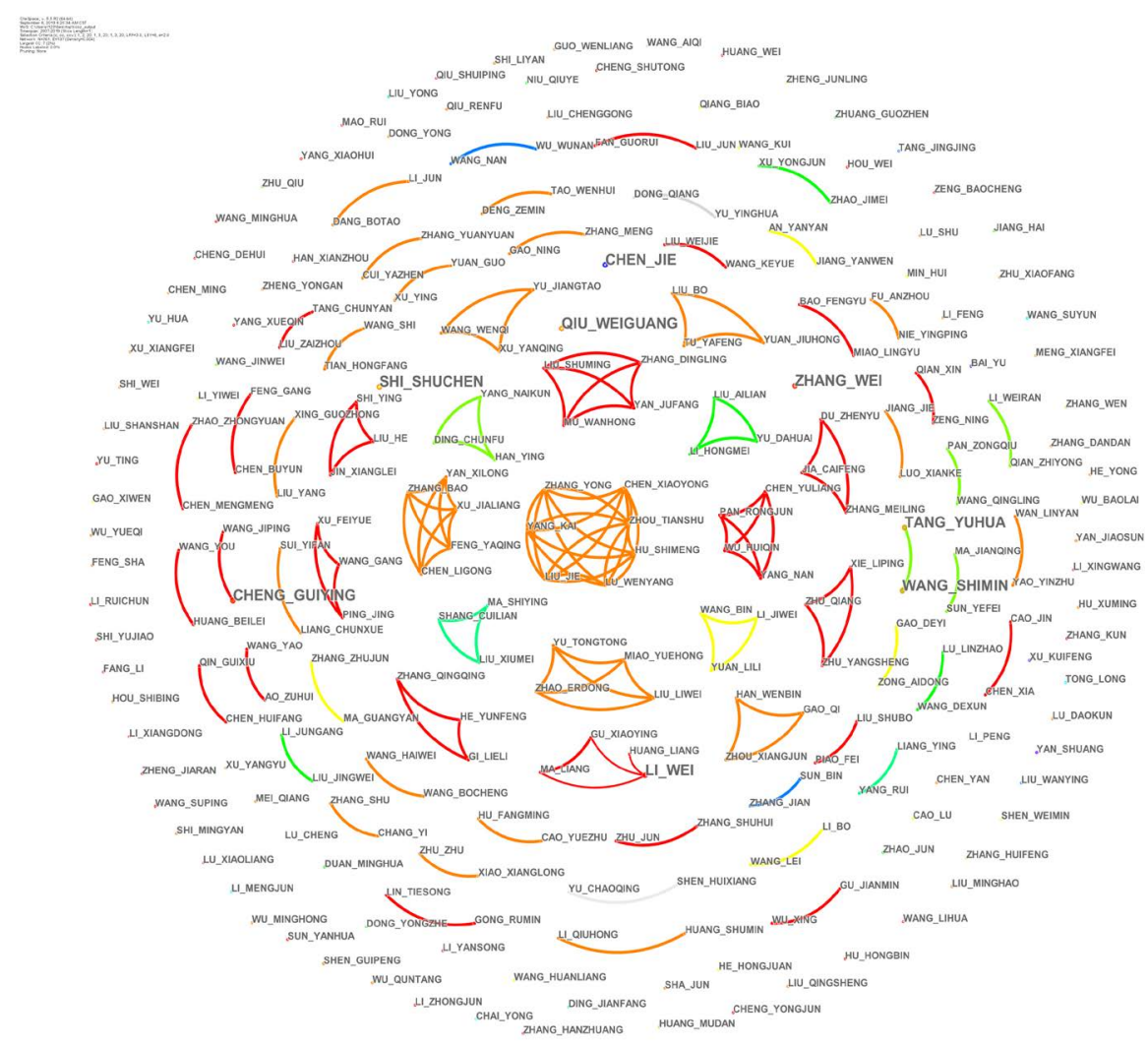

Figure 2. Curriculum ideological and political author cooperation network map (20072019).

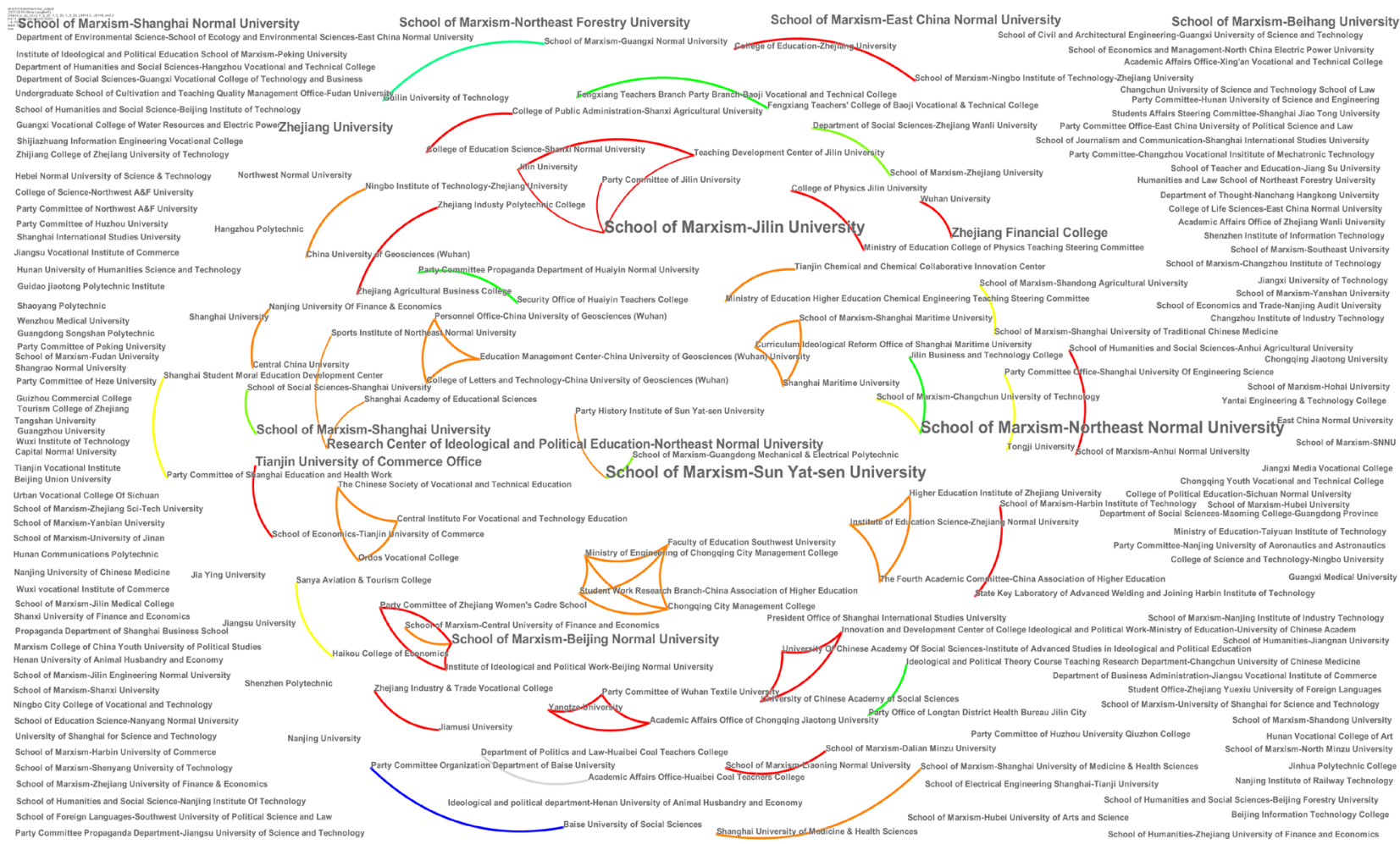

Figure 3. Curriculum ideological and political institutions cooperation network map (2007-2019). 
Education, Faculty of Education of Southwest University, Chongqing City Management College and its Ministry of Engineering. And there is no cooperative relationship between the rest of the research institutions. It can be seen that a large part of research institutions in this field tend to publish their papers independently, with less inter-agency collaboration, and the scale and depth of cooperation need to be further expanded.

\section{The Analysis of the Hotspots of Curriculum Ideological and Political Research}

In order to explore the research hotspots in the field of ideological and political studies, this paper selects keywords as the measurement indicators, and imports the conversion data into CiteSpace software and sets the analysis time interval to 2007-2019. The time slice is 1 year, and the analysis items are keywords (Keyword), the selected thresholds (Thresholds) are (1, 2, 20;1, 3, 20;1, 3, 20), and after appropriate adjustment, the course ideological and political keyword co-occurrence map (Figure 4) is obtained. To ensure the scientific nature of the analysis, the theme keyword "ideology and politics teaching in all course" has been hidden from the picture.

According to the law of Price, the high-frequency keyword calculation formula is $M_{k}=0.749 * \sqrt{N_{\max }}$, where $M_{k}$ is the high-frequency keyword threshold and $N_{\max }$ is the highest value of the keyword appearance frequency in the academic interval. It can be seen from the above figure that the "ideological and political theory education" node is the largest, and the frequency is the highest frequency except for the topic "ideology and politics teaching in all course". The frequency is 23, and the high frequency in the field can be calculated by Price's law. The keyword threshold $M_{k} \approx 3.59$, so the keyword with a frequency of not less than 4 can generally be used as the high frequency keyword studied in this paper. Considering that the intermediary centrality is the core indicator reflecting the position and importance of each keyword in the co-occurrence network, the centrality of the sample document keywords is generally low, and the larger part of the keyword centrality is 0. For easy observation and research, this paper includes keywords with a centrality greater than 0.01 into the scope of the study. Therefore, this paper combines the frequency and centrality of keywords to screen important keywords in the field, and obtain 21 high-frequency keywords (Table 1). On this basis, combined with the actual situation of the curriculum ideological and political research, the following important research hotspots are summarized.

\subsection{Cognition of the Concept of Curriculum Ideological and Political Education}

The key words of this theme mainly include "ideological and political theory course", "ideological and political course", "ideological and political class", "political and ideological course in university", "ideological \& political theory course in university", "same direction and same action", "establishing morality and cul 


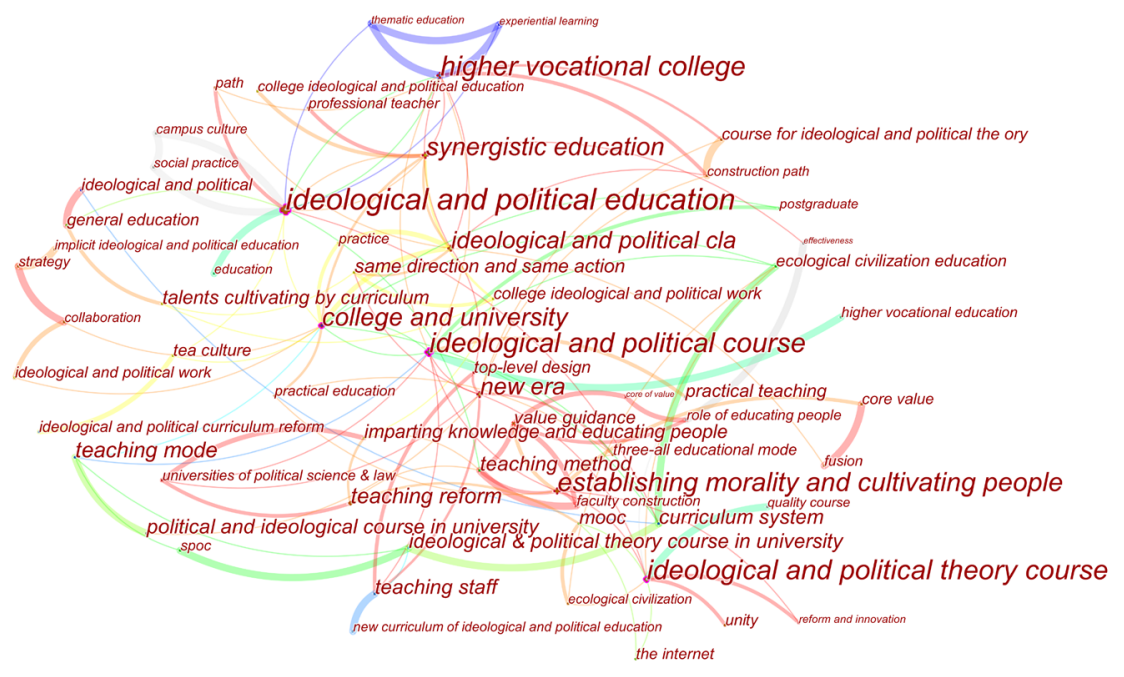

Figure 4. Curriculum ideological and political keyword co-occurrence map (2007-2019).

Table 1. Curriculum ideological hotspot keywords.

\begin{tabular}{|c|c|c|c|}
\hline Centrality & Frequency & Keywords & Year \\
\hline 23 & 0.30 & ideological and political education & 2007 \\
\hline 17 & 0.29 & ideological and political course & 2010 \\
\hline 17 & 0.26 & ideological and political theory course & 2007 \\
\hline 16 & 0.16 & higher vocational college & 2011 \\
\hline 13 & 0.27 & college and university & 2010 \\
\hline 12 & 0.08 & ideological and political class & 2017 \\
\hline 12 & 0.11 & synergistic education & 2017 \\
\hline 11 & 0.18 & establishing morality and cultivating people & 2018 \\
\hline 9 & 0.18 & new era & 2018 \\
\hline 6 & 0.05 & teaching reform & 2018 \\
\hline 5 & 0.04 & same direction and same action & 2017 \\
\hline 5 & 0.06 & political and ideological course in university & 2008 \\
\hline 5 & 0.07 & ideological \& political theory course in university & 2013 \\
\hline 5 & 0.02 & imparting knowledge and educating people & 2017 \\
\hline 5 & 0.10 & curriculum system & 2012 \\
\hline 5 & 0.10 & teaching mode & 2012 \\
\hline 4 & 0.04 & talents cultivating by curriculum & 2017 \\
\hline 4 & 0.06 & mooc & 2016 \\
\hline 4 & 0.03 & ideological and political work & 2017 \\
\hline 4 & 0.04 & practical teaching & 2007 \\
\hline 4 & 0.09 & teaching staff & 2012 \\
\hline
\end{tabular}


tivating people", "imparting knowledge and educating people". In 2016, on the basis of grasping the pulse of the development of China's higher education and college ideological and political education, Shanghai's education field put forward the proposition of "ideology and politics teaching in all course" around the reform of ideological and political education in colleges and universities. The proposition provided a "source of living water" for the continuous enrichment of the curriculum's ideological and political ideas. Many scholars have elaborated on the concept of "the curriculum ideological and political education" from two aspects: the basic connotation and the distinction between related concepts.

\subsubsection{About the Basic Connotation}

For the scientific connotation of the curriculum ideological and political education, domestic scholars have carried out a richer interpretation from different levels. From the perspective of essence, Gao \& Zong (2017) believed that the essence of "the curriculum ideological and political education" was "integrate ideological and political education in Colleges and universities into all aspects of curriculum teaching and reform", so as to achieve the goal of establishing morality and cultivating people, rather than opening a new course or adding an activity. Min (2017) recognized that in order to meet the inherent requirement of the reform of ideological and political education in colleges and universities, it was necessary to understand and grasp the scientific connotation of "curriculum ideological and political education" from a strategic point of view on the basis of establishing morality and cultivating people. From the medium level, Jiang \& Luo (2018) put forward the idea of "curriculum ideological and political education" on the basis of combining the goal of educating people with the inherent requirements of curriculum construction. It was pointed out that "curriculum ideological and political education" was a kind of ideological and political education resources which was fully tapped and integrated into the platform of university ideological and political education in all kinds of courses offered by colleges and universities, so as to form the idea of cultivating morality and cultivating people with the same direction and synergistic effect as the goal of ideological and political education. From the micro-perspective, Xiao \& Zhu (2018) interpreted curriculum ideological and political education from the perspective of curriculum teaching methods as: integrating knowledge imparting and value guiding in all curriculum teaching, extracting the value paradigms of patriotism, social responsibility, cultural self-confidence and humanistic spirit contained in the curriculum, so as to students have correct direction in knowledge, emotion and behavior.

\subsubsection{About the Distinction of Relevant Concepts}

1) The relationship between curriculum ideological and political education and ideological and political course

The ideological and political course seems to be the same as the curriculum ideological and political education, but in fact they are both related and differ- 
ent. On the one hand, most scholars believed that "curriculum ideological and political education "was closely related to "ideological and political course" and took actions in the same direction. For example, Qiu (2018) believed that "curriculum ideological and political education" complemented the relative "insufficiency" of "ideological and political course" in a certain sense. The peers and coordinated development of them had the inevitability of the times; Chen (2018) thought that "curriculum ideological and political education" was implicit, and "ideological and political course" was explicit. Both of them were in the same direction, and they unified in the fundamental issue of cultivating what kind of people, how to cultivate people and for whom to cultivate. On the other hand, some scholars explained the differences between "curriculum ideological and political education" and "ideological and political education courses". Min (2017) started from their different conceptual categories, emphasized that the former was a concept of curriculum and curriculum design, while the latter was a specific course. At the same time, some scholars made a comprehensive analysis of the relationship from the similarities and differences between "curriculum ideological and political education" and "ideological and political courses". For example, Shi (2018) believed that they had the same essential connection in tasks and objectives, directions and functions, contents and requirements, but they also had different emphasis on ideological and political content, curriculum status, curriculum characteristics and ideological and political advantages.

2) The relationship between ideological and political theory courses and other types of courses

General Secretary Xi Jinping's speech at the National College Ideological and Political Work Conference provided a new perspective for relevant scholars to examine and deal with the relationship between ideological and political theory courses and other courses. Shi, from the perspective of ideological and political education, showed that the ideological and political theory course was the main channel for ideological and political education for college students. Only by cooperating with ideological and political theory course in the same direction, can all kinds of courses successfully accomplish the fundamental task of establishing morality and cultivating people (Shi, 2017). Based on the interrelationship between the courses, Min (2017) pointed out that in the curriculum system established by "curriculum ideological and political education", the ideological and political theory courses and other various courses were independent and mutually unified, complement each other and reflect the goals and orientations of "curriculum ideological and political education", "combination of knowledge transfer and value leadership", "work together of explicit education and implicit education", and them served together the fundamental tasks of establishing morality and cultivating people. Xiao (2017) made a comprehensive analysis of the factors affecting the coordination and the basis for the conformity between ideological and political theory courses and other courses, then put forward the important viewpoint that ideological and political courses and other courses should establish a cooperative education mechanism. 


\subsection{The Theoretical Basis and Value Implication of Curriculum Ideological and Political Education}

This theme mainly includes high-frequency keywords "teaching reform" and "ideological and political education". "Curriculum ideological and political education" has a profound theoretical foundation and far-reaching value implication, which has caused continuous discussion in the domestic academic circles. At present, it has formed theoretical achievements of a certain scale and is becoming more mature.

\subsubsection{About the Theoretical Basis}

The course of thought comes into being with a scientific and solid theoretical basis, and some scholars have carried out valuable discussions on it. $\mathrm{Hu}$ (2019) scientifically demonstrated the inherent theoretical logic of Ideological and political construction of curriculum from three aspects: Marxist classical writers' comprehensive development theory of human beings, curriculum culture development theory and effective teaching theory. Shen (2018) based on the unconscious psychological role, conscious psychological role and contextual interaction psychology, carried out a characteristic analysis of the pan-syllabic ideological and political, which provided theoretical support for the curriculum ideological and political from the perspective of psychology. He (2017) explored the theoretical basis of the transformation from "ideological and political course" to "ideological and political course" from three aspects: the coupling of curriculum systematicness and synergy, the unity of curriculum rational value and instrumental value, and the integration of science education and humanities education.

\subsubsection{About the Value Implication}

Many domestic experts and scholars have carried out multi-dimensional analysis around the important value of "curriculum ideological and political education". Qiu (2017), based on the macro perspective, expounded the great value of "curriculum ideological and political work" in improving and strengthening ideological and political work in colleges and universities, realizing the requirements of "three-all" education, and comprehensively improving the level and quality of ideological and political work in colleges and universities; He (2017) pointed out clearly that "curriculum ideological and political education" was the need of the reform of university education concept and the necessity of the development of invisible ideological and political education concept; Min (2017) pointed out the prominent value of "curriculum ideological and political education" in promoting the current ideological and political education reform in colleges and universities from the perspective of practical significance. Liu (2018) focused on the value guidance level of curriculum ideological and political education, and proposed that we should deepen understanding of curriculum ideological and political work from the perspective of educational thought. 


\subsection{The Generation Path of Curriculum Ideological and Political Education}

The key words of this theme mainly include "synergistic education", "teaching mode" and "Ideological and political work". Domestic scholars have actively explored the path of curriculum ideological and political construction. It gradually formed the path of "three elements" and "four elements", which provided a realistic choice for our country to carry out curriculum ideological and political construction.

\subsubsection{About the "Three Elements" Path}

Gao (2017) analyzed the work mode of "curriculum ideological and political education" in Shanghai universities and emphasized the construction of curriculum ideological and political education from the aspects of establishing the concept of synergistic education, creating the main body of synergistic education, and constructing the working mechanism of synergistic education; Xiao \& Zhu (2018) started from the optimization design of "curriculum ideological and political education" and pointed out that the curriculum can be promoted from the aspects of development concept, platform construction and mechanism construction.

\subsubsection{About the "Four Elements" Path}

He (2017), starting from the inherent logic of curriculum politics, pointed out that the transformation of ideological and political education concept, the construction of big ideological and political model, the formation of educational community and the development of curriculum resources were the basic premise, basic requirements, basic support and necessity of curriculum ideological and political construction. Qiu (2017) believed that among the many factors affecting the formation of "curriculum ideological and political education" in colleges and universities, teachers were the key; teaching materials were the foundation; resource mining was a prerequisite; and system construction was the fundamental guarantee. Tan (2018) pointed out that the curriculum ideological reform should focus on strengthening top-level design, sticking to ideological and political teaching, focusing on curriculum operation, and focusing on curriculum development.

\subsection{Exploration of the Reform of Ideological and Political Education in the Curriculum}

The key words of this theme mainly are related to "curriculum system", "practical teaching”, "teaching staff", "higher vocational college”, "college and university", "talents cultivating by curriculum", "mooc" and "new era". Under the background of the new era, it is of far-reaching significance to promote the reform of ideological and political education in curriculum and to train a number of qualified builders and reliable successors of socialism with Chinese characteristics, in order to improve the development level of national higher educa- 
tion and build a well-off society in an all-round way, and then start a new journey of building a powerful socialist modernization country. Therefore, many domestic experts and scholars have made unremitting explorations on the teaching reform of curriculum ideological and political education from many aspects such as curriculum system setting, teaching methods, teaching staff building, subject responsibility implementation, and institutional mechanism building.

\subsubsection{About the Curriculum System Setting}

Gao \& Zong (2017) examined the national ideological strategy and pointed out that China's curriculum system should not only firmly grasp the core curriculum status of ideological and political theory courses in ideological and political education, but also give full play to the value of all other courses and build the three-in-one college ideological and political education curriculum system including ideological and political theory course, comprehensive literacy course and professional course. Liang \& Sui (2018) set out from the principle of curriculum system and believed that the construction of ideological and political theory curriculum system must be highly consistent with the goal of personnel training, must highlight the core curriculum and solve major theoretical problems, and must adhere to the combination of educational needs and educational effectiveness. Wang \& Wang (2018) proposed that the "curriculum ideological and political education" of colleges and universities should be structured with the "ideological and political courses" as the center, and the various courses should be well-defined and patched from the perspective of the curriculum system.

\subsubsection{About Teaching Methods}

Liu (2017) put forward the idea of realizing the deep integration of the Internet and curriculum teaching from the perspective of enhancing the affinity and pertinence of ideological and political work, and then highlighting the role of "ideology and politics" in courses. Wang \& Li (2017) fully realized the importance of the practical teaching of ideological and political theory courses in the ideological and political work of colleges and universities, and clearly proposed to make full use of the practical teaching of ideological and political courses, focusing on the principles of practical teaching, constructing the content system of practical teaching, exploring practical teaching paths, thus strengthening and promoting ideological and political work in colleges and universities. Chen (2019) pointed out the value-leading role of "curriculum ideological and political education" and emphasized that teaching methods should focus on the unity of classroom teaching, social practice and network application.

\subsubsection{About the Construction of the Teaching Staff}

Wu (2018), cutting through the prominent realities presented by Teacher, Please

Don't Introduce China like This, pointed out that the key to running "curriculum ideological and political education" was to give full play to the leading role 
of ideological and political teachers in the teaching staff. $\mathrm{Hu}$ (2018) considered that the teachers and counselors of ideological and political theory courses were the main force of ideological and political education in colleges and universities. He suggested that the integration of the two teams should be strengthened so as to promote the work of adult talents and moral cultivators of college students to achieve practical results. Wei et al. (2019) discussed the basic principles and practical mechanism of the construction of ideological and political course teachers in higher vocational colleges in the new era from the perspective of ideological and political education in higher vocational colleges.

\subsubsection{About the Implementation of the Main Responsibility}

Li (2017) pointed out that the Party committees in colleges and universities shouldered the main responsibility of promoting ideological and political work. In the reform of curriculum ideological and political education, they should strengthen their political responsibility of grasping the overall situation and direction, the organizational responsibility of establishing the relevant mechanism and the promotion responsibility of implement the reform plan. Gao \& Zong (2017) further pointed out that in the process of exploring the implementation of the ideological and political reform of colleges and universities, adhering to the "establishing morality and cultivating people" is the sacred mission of all educators, should not only be included in the main responsibilities of party organizations at all levels in colleges and universities, but should also become the responsibility of teachers, cadres and workers.

\subsubsection{About the Institutional Mechanism Building}

$\mathrm{Yu}$ (2018) advocated the establishment of a cooperative mechanism of work involving multiple elements, a clear-cut evaluation mechanism, an authoritative and efficient leadership management system and a perfect talent support system, from the perspective of peer education of professional courses and ideological and political courses in colleges and universities. $\mathrm{Hu}(2019)$ analyzed the subjective and objective problems faced by colleges and universities in the process of promoting the ideological and political construction of the curriculum. From the perspective of promoting the scientific development of curriculum development, he proposed the solution of constructing the concept guiding system, the responsibility implementation system, the coordination system, and the resource integration. $\mathrm{Wu}$ (2019) believed that in order to realize the transformation from "ideological and political courses" to "curriculum ideological and political education", we should establish an effective leadership mechanism, improve the teaching evaluation system, form a scientific incentive mechanism, and innovate a mechanism for educating people, so as to ensure the real implementation of curriculum ideological and political education.

\section{The Evolutionary Trend Analysis of Curriculum Ideological and Political Research}

First, use CiteSpace to co-occurate the keywords, then set the visual graphics 
style to "Timezone", and finally adjust the label appropriately to get the time zone distribution of the curriculum ideological and political keywords (Figure 5). From the keyword content and the essence, we can clearly see the two major trends in the development of curriculum ideological and political research in China in 2007-2019.

\subsection{From "Ideological and Political Course" to "Ideology and Politics Teaching in All Course"}

From the content point of view, in 2007-2016, the domestic academic circles have mainly carried out practical research around the "ideological and political courses" and have achieved relatively fruitful results, which is mainly reflected in the diversification of teaching methods ("practical teaching", "social practice", "experiential learning, "mooc", "the Internet", etc.), the expansion of service objects ("college and university", "higher vocational college", "postgraduate", etc.), the enrichment of teaching content ("campus culture", "thematic education", "ideological and political education", "ecological civilization education", "general education"), multidimensional reform of curriculum ("ideological and political curriculum reform", "teaching staff", "teaching model", "curriculum system"). The related research on the ideological and political course has promoted the birth of the curriculum ideological and political concept in a sense. From 2017 to 2019, with the formal formulation of the curriculum's ideological and political concept and the Party Central Committee's high attention to ideological and political work, many scholars began to focus on the "curriculum ideological and political education" research, which greatly promoted the development of

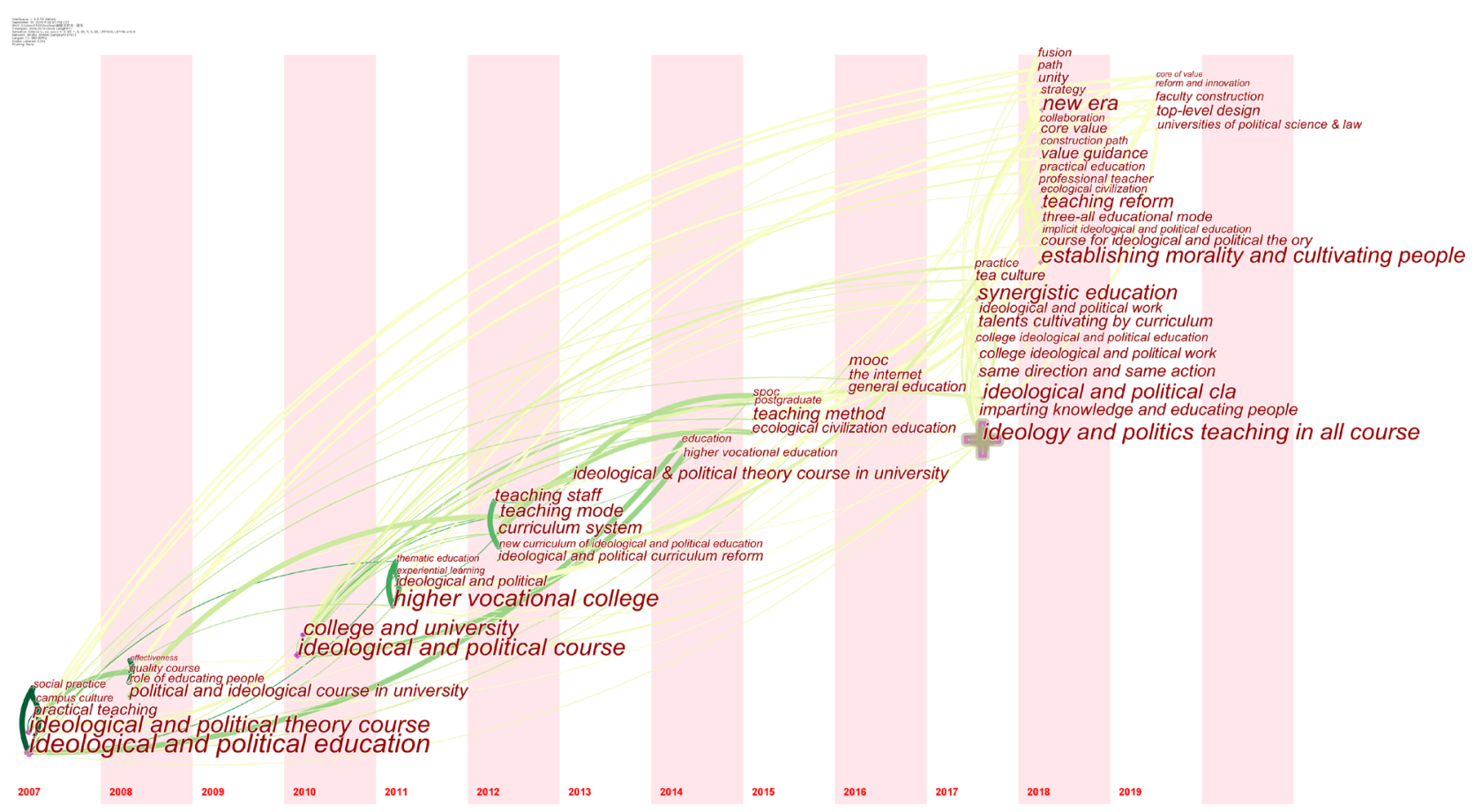

Figure 5. Curriculum ideological and political keyword time zone distribution map (2007-2019). 
cognition of the concept ("same direction and same action", "ideological and political course", etc.), discussion of value ("value guidance", "core of value”, etc.), generation of path ("synergistic education", "collaboration", etc.) and exploration of reform ("reform and innovation", "top-level design", etc.) in this field.

\subsection{From "Two Skins" to "Melting Furnace"}

In essence, for a long time, many educators have the idea that ideological and political education is the responsibility of ideological and political teachers and the proper meaning of ideological and political courses, expecting to "do their best in one campaign", while for other kinds of courses, ideological and political education is not necessary. This has resulted in the increasingly "isolated" ideological and political education, forms a prominent problem of "two skins" between ideological and political education and professional education. With the continuous development of practice and the deepening of research, people gradually realize that in order to break the grim situation of "two skins" in ideological education, we must set up the core idea of "curriculum ideological and political education" and build a "melting furnace "of 360-degree moral education in school education, starting from the essential requirement of "educating people" in higher education, so as to build the ideological and political education system for college students in an all-round, whole-process and all-staff way. (Gao \& Zong, 2017).

\section{Conclusion and Discussion}

\subsection{Conclusion}

With the software Citespace, this paper makes a visual analysis of 175 journal papers in CNKI journals from 2007 to 2019, including SCI source journals, EI source journals, core journals, CSSCI journals and CSCD journals with the theme of "curriculum ideological and political education", and describes intuitively the current research situation, research hotspots and evolution trend in the field. Potentially, following conclusions are drawn.

1) Through analyzing the annual distribution of periodical papers, the cooperation of authors and institutions in this field, the current research situation in the field of curriculum ideological and political education is preliminarily explored. The results show that the curriculum's ideological and political education has become a hot research topic in domestic academic circles, and its high heat will continue in the future. Degree and cooperation links of authors need to be further strengthened; the scale and depth of cooperation of research institutions need to be further expanded.

2) Through the comprehensive analysis of keyword frequency and its centrality, four research hotspots of curriculum ideological and political education are identified: the ideological cognition of curriculum ideological and political, the theoretical basis and value implication, the generating path and the exploration of educational reform. Specifically, domestic scholars mostly enhance their un- 
derstanding of the ideological and political concepts of curriculum in the view of the distinction between basic connotations and related concepts; discuss the theoretical basis and value implication of curriculum ideological and political education from multiple dimensions; research generating path of curricular ideological and political education from the "three elements" path and the "four elements" path; explore the teaching reform from five aspects: curriculum system setting, teaching methods, construction of teaching staff, implementation of subjective responsibility and building of institutional mechanism.

3) Through the analysis of the distribution characteristics of keyword time zones, it is found that there are two main trends in the research of curriculum ideological and political education in China, namely, from the "ideological and political course" stage to the "ideology and politics teaching in all course" stage and from the "two skins" stage to the "melting furnace" stage.

\subsection{Discussion}

This paper intuitively shows the development prospect of curriculum ideological and political education in China. It not only provides effective help for relevant personnel to deepen their understanding of curriculum ideological and political education, but also provides a new research perspective and scientific reference for this field. However, due to the limited sample space at present, it may not be possible to analyze the specific situation of curriculum ideological and political education in China comprehensively only from the perspective of authors, institutions and keywords.

Even so, the analysis of current situation, hotspots and evolutionary trend of domestic curriculum ideological and political research shows that the current domestic research on curriculum ideological and political education has achieved preliminary results. But the curriculum ideological and political construction is still in the exploratory stage, many scholars have studied this field from the theoretical level, and there are still shortcomings based on research at the practical level. Under the new situation, experts and scholars should strengthen the study of the practical paths by jointly introducing curriculum ideological and political education into course teaching, so as to provide an operational and reproducible implementation paradigm for relevant practices.

\section{Acknowledgements}

This research is financially supported by the Research and Planning Fund for Humanities and Social Sciences of Jiangxi education department named "Research on the mechanism and policies of environmental regulations affecting green economic growth-a case study of the Yangtze River Economic Belt" (GL18125), and Social Science Foundation of Jiangxi (18GL09), Research of teaching reform in universities in Jiangxi Province (JXJG-18-2-42).

\section{Conflicts of Interest}

The authors declare no conflicts of interest regarding the publication of this paper. 


\section{References}

Chen, Y. (2018). On the Interaction and Integration of "Ideological and Political Courses" and "Curriculum Ideological and Political Education" in Higher Vocational Colleges. Leading Journal of Ideological and Theoretical Education, 12, 110-112.

Chen, Z. B. (2019). Construction and Improvement of Teaching Staff Guided by "Curriculum Ideological and Political Education”. Course Education Research, 14, 82.

Gao, D. Y., \& Zong, A. D. (2017). From Ideological and Political Courses to Curriculum Ideological and Political Education: Constructing the Ideological and Political Education Curriculum System in Colleges and Universities from a Strategic Perspective. China Higher Education, 1, 43-46.

Gao, X. W. (2017). Research on the Ideological and Political Work Model of College Courses Based on Collaborative Education-Taking Shanghai University Reform Practice as an Example. The Party Building and Ideological Education in Schools, 24, 16-18.

He, H. J. (2017). The Internal Logic and Construction Strategy of the Development from "Ideological and Political Courses" to "Curriculum Ideological and Political Education". Ideological and Political Education Research, 33, 60-64.

$\mathrm{Hu}, \mathrm{H}$. B. (2019). Course of Ideological and Political Education: From Theoretical Basis to System Construction. Chongqing Higher Education Research, 7, 112-120.

Hu, X. M. (2018). Functional Positioning and Implementation Countermeasures of Teachers and Counselors in College Ideological and Political Cooperate to Educate People. Academic Forum, 41, 174-180.

Jiang, J., \& Luo, X. K. (2018). Research on the Path of the Construction of Curriculum Ideological and Political Education in Colleges and Universities in the New Era. Chinese Vocational and Technical Education, 32, 84-87.

Li, J. (2017). Pilot Courses: The Logic and Action of the Party's Main Responsibility. China Higher Education, Z3, 18-20.

Liang, C. X., \& Sui, Y. F. (2018). Curriculum System Reconstruction: Investigation and Thinking Based on the Pertinence and Affinity of Strengthening Ideological and Political Theory Courses. China Higher Education Research, 11, 63-70.

Liu, C. G. (2018). Some Thoughts on Further Promoting the "Curriculum Ideological and Political Education" in Colleges and Universities. Ideological and Theoretical Education, 6, 62-67.

Liu, S. H. (2017). Theoretical Research on the Construction of "Internet + Curriculum Ideological and Political Education” Model. China Higher Education, Z3, 15-17.

Min, H. (2017). Curriculum Ideological and Political Education and Social Sciences Education in Colleges and Universities. Ideological and Theoretical Education, No. 7, 21-25.

Qiu, R. F. (2018). Theoretical Interpretation of Peering Ideological and Political Education and Ideological and Political Courses in the Same Direction. Studies in Ideological Education, No. 4, 109-113.

Qiu, W. G. (2017). The Value Implication and Generation Path of Curriculum Ideological and Political Education. Ideological and Theoretical Education, No. 7, 10-14.

Shen, G. P. (2018). Illumination of Characteristic of Ideological and Political Education in All Courses in Sight of Psychology. Ideological and Theoretical Education, No. 9, 66-71.

Shi, S. C. (2017). Same Direction and Same Action: The Focus of the Collaborative Innovation of Ideological and Political Education in Colleges and Universities. Ideological and Theoretical Education, NO.7, 15-20. 
Shi, S. C. (2018). To Understand Correctly the Relationship between "Ideological and Political Courses" and "Ideological and Political Education by Courses". Ideological and Theoretical Education, 11, 57-61.

Tan, X. S. (2018). Analysis of the Value Connotation and Practice Path of Curriculum Ideological and Political Education. Study on the Ideological and Political Work, No. 4, 44-45.

Wang, H. W., \& Wang, B. C. (2018). On the Core Essentials and Practice Path of College Curriculum Ideological and Political Education. The Party Building and Ideological Education in Schools, 14, 32-34.

Wang, L., \& Li, B. (2017). Research on the Implementation Strategy of Practical Teaching of Ideological and Political Theory Courses in Colleges and Universities in the New Era. Leading Journal of Ideological \& Theoretical Education, 10, 103-106.

Wei, Q. J., Lin, L. L., \& Xu, Y. (2019). Reflections on the Construction of Teachers' Team of Ideological and Political Theory Courses in Higher Vocational Colleges. Beijing Education (Moral Education), No. 6, 93-96.

Wu, G. C. (2019). Analysis of the Change from "Ideological and Political Courses" to "Putting Ideological and Political Work into the Process of Ideological and Political Course". Journal of Inner Mongolia Agricultural University (Social Science Edition), 21, 40-43.

Wu, Q. T. (2018). On the Leading Role of Ideological and Political Theory Teachers in School Teachers-Based on the Perspective of Curriculum Ideological and Political Education. The Party Building and Ideological Education in Schools, 11, 70-72.

Xiao, X. L., \& Zhu, Z. (2018). Exploration and Practice of Curriculum Ideological and Political Education under the Pattern of "Great thought and Politics". Leading Journal of Ideological and Theoretical Education, 10, 133-135.

Xiao, X. L. (2017). The Ideological and Political Education and Other Courses Must Establish a Collaborative Education Mechanism. China Higher Education, 23, 14-15.

Yu, X. H. (2018). The Three Dimensions of College Students' Professional Courses and Ideological and Political Courses Peering Together. Culture and Education Materials, 26, 166-167. 